\title{
Variation in the chemical composition of Amazonian woods submitted to decay fungi
}

\author{
Lissyanne Fleury Santos Vieira' ${ }^{1}$, Alexandre Florian da Costa $^{1} \oplus$, Alessandro Cézar de Oliveira Moreira ${ }^{2}$ \\ 1 Universidade de Brasilia, Brasilia-DF, Brasil. E-mail: lissyfleury@gmail.com; lucate@unb.br \\ ${ }^{2}$ Serviço Florestal Brasileiro, Laboratório de Produtos Florestais, Brasília-DF, Brasil. E-mail: alessandro.moreira@florestal.gov.br
}

ABSTRACT: As a biological material, wood is susceptible to the action of xylophagous agents, which alter its physical and chemical properties, with the decay fungi standing out among these, causing damage and changing the chemical composition of the wood, as a result of the metabolism of its components. This study evaluated changes of the main chemical components of four Amazonian wood species after the attack of two decay fungi by means of gravimetric chemical analysis and mid-infrared spectroscopy. The chemical analyzes allowed distinguishing the action mechanisms of the fungi in relation to the chemical components of the wood. Overall, after the action of the Gloeophyllum trabeum fungus (brown rot), a reduction in the holocellulose proportion was observed, while for Trametes versicolor (white rot) it was a reduction of lignin. With the principal component analysis (PCA) results, it was possible to separate the treatments per wood, by using its mass loss and chemical components. It was also possible to differentiate the decay fungi by using the absorbance band intensities of the mid-infrared spectrum. As a conclusion, the mid-infrared spectroscopy has proved to be a useful tool in distinguishing classes of decay fungi. Further researches on this may contribute to create a more robust database for the identification of decay fungi action in wood.

Key words: mid-infrared; principal component analysis; tropical timbers; xylophagous fungi

\section{Variação na composição química de madeiras da Amazônia submetidas a fungos apodrecedores}

RESUMO: Por ser um material de origem biológica, a madeira está susceptível a ação de agentes xilófagos, que alteram suas propriedades físicas e químicas, com destaque para os fungos apodrecedores que causam danos e alteram a composição química da madeira em consequência da metabolização de seus componentes. O presente estudo avaliou a alteração dos principais componentes químicos de quatro madeiras da Amazônia, após o ataque de dois fungos apodrecedores, por meio da análise química gravimétrica e da espectroscopia de infravermelho médio. As análises químicas permitiram distinguir os mecanismos de ação dos fungos em relação aos componentes químicos da madeira. Em geral, após a ação do fungo Gloeophyllum trabeum (podridão parda) foi observada uma redução na proporção de holocelulose, e de lignina para o Trametes versicolor (podridão branca). Mediante a análise de componentes principais (PCA), foi possível separar os tratamentos pelas madeiras, utilizando os dados de perda de massa e dos seus componentes químicos. Também foi possível a distinção entre os fungos apodrecedores utilizando as intensidades das bandas de absorbância dos espectros de infravermelho médio. A espectroscopia no infravermelho médio mostrou ser uma ferramenta útil na distinção entre as classes de fungos apodrecedores. $O$ aumento de pesquisas com esse foco, pode favorecer a construção de uma base de dados mais robusta para a identificação dos fungos apodrecedores em ação nas madeiras.

Palavras-chave: infravermelho médio; análise de componentes principais; madeiras tropicais; fungos xilófagos 


\section{Introduction}

Wood is a heterogeneous material from biological origins susceptible to deterioration by fungi and xylophagous insects that metabolize its main components, changing their properties (Carneiro et al., 2009; Rudakiya \& Gupte, 2019). Decay fungi have prominent role in the evaluation of the natural resistance of wood, in view of their different deterioration mechanisms and the consequent wood mass loss (Carneiro et al., 2009). Thereby, the same given wood can have different resistance levels depending on the fungus (Costa et al., 2011). Thus, studies that evaluate different species submitted to different conditions and/or deteriorating agents broaden the knowledge of the resistance properties of wood.

Knowledge of the wood properties is of utmost important when aiming at a rational and efficient use of this material (Paes et al, 2004; Stangerlin et al., 2011). Knowing the natural resistance of the commercialized wood allows for a more suitable use, the need or not for chemical treatment, as well as reducing the expenses with replacement of pieces, and the impacts on remnant forests.

Infrared spectroscopy has been used to evaluate the chemical composition of wood in a fast, simple and nondestructive way (Lazzari et al., 2018; Rudakiya \& Gupte, 2019). Tsuchikawa \& Kobori (2015) suggest several applications, such as in the characterization of archaeological wood (Traoré et al., 2016), in photodegradation monitoring (Varga et al., 2017), in the distinction between treatments (Pandey \& Pitman, 2003; Labbé et al., 2006) and the monitoring of material under degradation (Rudakiya \& Gupte, 2019). Its joint use with the conventional chemical analysis allows the comparative monitoring of the chemical composition of wood subjected or not to biological deterioration.

The absorbance bands in the medium infrared spectrum are related to the bonds vibrations that may be indicative of more than one functional group, with the relation between these bands and the molecular structures of the wood samples classified as complex (Li et al., 2011; Traoré et al., 2016; Rudakiya \& Gupte, 2019).

Using multivariate statistical analysis, such as principal component analysis (PCA), in addition to allowing grouping variables by similarity, it also allows observing possible similarities and/or differences not always visually detectable between the samples (Traoré et al., 2016 ; Lazzari et al., 2018; Rudakiya \& Gupte, 2019). Mahajan et al. (2012) used PCA together with infrared spectroscopy to monitor changes in material subjected to white rot.

Therefore, the present study evaluated the variation in the chemical composition of four wood species from the Amazon subjected to attack by two decay fungi, by using medium infrared spectroscopy and conventional chemical analysis.

\section{Materials and Methods}

\section{Obtaining material and specimens}

The following four Amazonian wood species were selected: Simarouba amara Aubl (marupá), Ceiba pentandra
(L.) Gaertn. (sumaúma or kapok), Micropholis melinoniana Pierre (curupixá) and Amburana cearenses (Allemão) A.C. Smith (cerejeira or Amburana), marketed in the timber market of Brasília, all belonging to different classes of basic specific gravity.

For each wood, two boards with average dimensions of $400 \times 20 \times 8 \mathrm{~cm}$ (length $\times$ width $\times$ thickness) were obtained, and from them the specimens were made with the dimensions of $2.5 \times 2.5 \times 0.9 \mathrm{~cm}$, with the axial direction as the smallest.

\section{Determination of basic specific gravity}

For determining the basic specific gravity, 10 specimens per species were used, with nominal dimensions of $2.0 \times 2.0$ $x 10.0 \mathrm{~cm}$, according to the ASTM D2395 standard (ASTM, 2014). The specific gravity classes were defined according to Melo et al. (1990).

\section{Accelerated laboratory decay test}

The accelerated decay test was conducted based on the ASTM D 2017 standard guidelines (ASTM, 2005), with some modifications. 120 specimens were used for each combination of wood species versus decay fungus. Two decay fungi were used, one responsible for the brown rot (Gloeophyllum trabeum) and the other for the white rot (Trametes versicolor). In addition to these combinations, 70 specimens per wood species were also used, following the entire accelerated test process minus fungi action, which were set as reference for comparison with those subjected to said action.

Prior to the exposure to decay fungi, the initial weight of the specimens were determined, and after the 16-week period from the fungi attack, the mass losses in these specimens were determined.

Diffuse reflectance spectroscopy in the medium infrared (DRIFT-MIR)

The medium infrared spectra (MIR) were obtained by using a Bruker spectrophotometer, model Tensor 37, equipped with a diffuse reflectance device (DRIFT). The absorbance was determined on the transversal face of the specimen, in triplicates, using 24 scans with resolution of $4 \mathrm{~cm}^{-1}$.

The mean spectra value for each treatment (wood $\mathrm{x}$ decay fungus), was obtained using the OPUS 6.5 software, with the fingerprint defined between 1900 and $800 \mathrm{~cm}^{-1}$ and individualization of the bands of interest. Table 1 displays the

Table 1. Position of the bands of interest and the assignments of the medium infrared spectra.

\begin{tabular}{|c|c|c|}
\hline $\begin{array}{c}\lambda \\
\left(\mathrm{cm}^{-1}\right)\end{array}$ & Assignments & $\begin{array}{l}\text { Chemical } \\
\text { component }\end{array}$ \\
\hline 1510 & vs $(\mathrm{C}=\mathrm{C})$ [aromatic ring] & Lignin $1,2,3,4,5,6$ \\
\hline 1375 & $\delta a s(C-H)$ & Cellulose and hemicellulose 2,5 \\
\hline 1160 & $\operatorname{vas}(\mathrm{C}-\mathrm{O}-\mathrm{C})$ & Cellulose and hemicellulose $2,3,5$ \\
\hline 1135 & vs $(\mathrm{C}-\mathrm{O}-\mathrm{C})$ & Hemicellulose 2,5 \\
\hline 899 & $\operatorname{\delta as}(\mathrm{CH})$ & Cellulose $2,5,6$ \\
\hline
\end{tabular}

$\lambda$ : wavelength, $v$ : stretching, $\delta$ : deformation, as: asymmetric, s:simmetrical. ${ }^{1}$ Duca et al. (2016), , ${ }^{2}$ ackler et al. (2010), ${ }^{3}$ González-Peña \& Hale (2011), ${ }^{4}$ Gupta et al. (2015), ${ }^{5}$ Varga et al. (2017), ${ }^{6}$ Rudakiya \& Gupte (2019). 


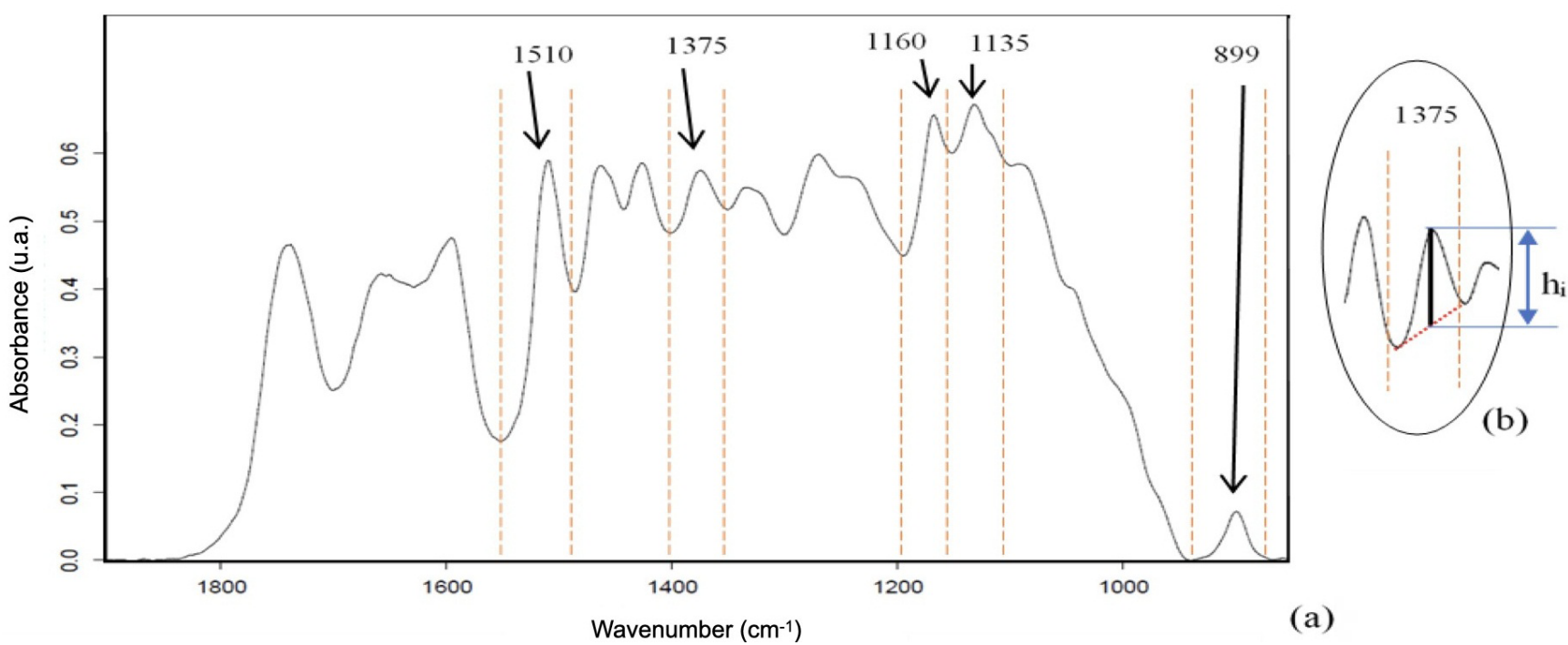

Figure 1. (a) Spectrum in the medium infrared demonstrating the bands of interest, limit defined by the dashed lines and the band peak indicated by the arrow, (b) highlight of the $1375 \mathrm{~cm}^{-1}$ band, indicating the height $\left(h_{i}\right)$ relative to the adjacent valleys, referring to the calculated integral.

bands of interest and Figure 1 details the analyzed spectrum, as well as the value of the absorbance intensity integral (hi).

\section{Gravimetric chemical analysis}

For the gravimetric chemical analysis, the specimens were reduced in fraction particles between 40-60 mesh. This material, used in triplicates, serves to determine the extractives content in ethanol:toluene 1:2 (v/v). From the extractive-free material, the contents of insoluble and soluble extractive-free acid lignin, as well as from extractive-free ash at $525^{\circ} \mathrm{C}$ were determined. The determination criteria followed the Protocol adopted by the Forest Products Laboratory of the Brazilian Forest Service (LPF/SFB), based on the standards TAPPI - 204 om88 (TAPPI, 1988), LAP \#003 (Templeton \& Ehrman, 1995), LAP \#004 (Templeton \& Ehrman, 1995) and TAPPI - 211 om93 (TAPPI, 1993), respectively. The extractive-free holocellulose content was determined according to Equation 1.

$$
\mathrm{Hc}_{\text {e.f. }}=100 \%-\mathrm{LT}_{\text {e.f. }}(\%)-\mathrm{Cz}_{\text {e.f. }}(\%)
$$

in which: $\mathrm{Hc}_{\text {e.f. }}$ - content of extract-free holocellulose, in percentage (\%); $\mathrm{LT}_{\text {e.f. }}$ - content of total extract-free lignin, sum of insoluble and soluble acid lignin; $\mathrm{Cz}_{\text {e.f. }}$ - content of extractfree ash at $525^{\circ} \mathrm{C}$.

\section{Statistical analysis}

Results from the mass loss of the specimens were subjected to the factorial analysis of variance and the means comparison by the Tukey test at $5 \%$ significance. The results from the chemical gravimetric analysis and the spectroscopy were subjected to principal component analysis (PCA), by using the Past 3.21 software (Hammer et al., 2001). Regarding the spectroscopy, intensity values were used inside the fingerprint, which were pre-processed by signal standardization (SNV - Standard normal variate), minimizing the scattering, while values obtained by gravimetric chemical analysis and mass loss were pre-processed by auto escalation, both aided by Microsoft Excel ${ }^{\circledR}$.

\section{Results and Discussion}

\section{Mass loss and basic density}

Table 2 demonstrates that regardless of the used fungus, the wood species received the same resistance classification. Simarouba amara and Ceiba pentandra, classified as having low basic specific gravity (Melo et al., 1990), were considered to be little resistant or not at all, with mass loss greater than $45 \%$, with C. pentandra displaying the greatest mass loss after the attack of the Trametes versicolor fungus (61\%). Microphilis melinoniana and Amburana cearense, classified as with medium basic specific gravity, were considered as moderately resistant and resistant, respectively, to both decay fungi.

The deterioration pattern of the decay fungi, whether from white or brown rot, varied according to the wood (Mahajan et al., 2012), which may be related to its chemical composition.

Table 2. Mass loss, resistance classes and basic specific gravity of the wood species, with their respective standard deviations.

\begin{tabular}{|c|c|c|c|}
\hline \multirow{2}{*}{$\begin{array}{l}\text { Species/ } \\
\text { Fungi }\end{array}$} & \multicolumn{2}{|c|}{ Mass loss (\%) } & \multirow{2}{*}{$\begin{array}{c}\text { Basic specific } \\
\text { gravity } \\
\left(\mathrm{g} \mathrm{cm}^{-3}\right)\end{array}$} \\
\hline & $\begin{array}{c}\text { Gloeophyllum } \\
\text { trabeum }\end{array}$ & $\begin{array}{l}\text { Trametes } \\
\text { versicolor }\end{array}$ & \\
\hline $\begin{array}{l}\text { Simarouba } \\
\text { amara }\end{array}$ & $\begin{array}{c}47.18(6.49) \mathrm{Aa} \\
\text { LNR }\end{array}$ & $\begin{array}{c}46.97(6.54) \mathrm{Ab} \\
\text { LNR }\end{array}$ & $0.35(0.007)$ \\
\hline $\begin{array}{l}\text { Ceiba } \\
\text { pentandra }\end{array}$ & $\begin{array}{c}46.63(6.54) \mathrm{Ba} \\
\text { LNR }\end{array}$ & $\begin{array}{c}60.97(4.30) \mathrm{Aa} \\
\text { LNR }\end{array}$ & $0.46(0.013)$ \\
\hline $\begin{array}{l}\text { Microphilis } \\
\text { melinoniana }\end{array}$ & $\begin{array}{c}37.79(6.08) A b \\
M R\end{array}$ & $\begin{array}{c}31.68(3.77) \mathrm{Bc} \\
\mathrm{MR}\end{array}$ & $0.59(0.015)$ \\
\hline $\begin{array}{l}\text { Amburana } \\
\text { cearenses }\end{array}$ & $\begin{array}{c}15.15(2.05) A c \\
R\end{array}$ & $\begin{array}{c}14.32(4.41) \mathrm{Ad} \\
\mathrm{R}\end{array}$ & $0.61(0.038)$ \\
\hline
\end{tabular}

Values in parentheses refer to the standard deviation. Means followed by the same uppercase letter in the row and the same lowercase letter in the column do not differ statistically. LNR: little or no resistant, MR: moderately resistant, R: resistant. 
Thus, the difference found in the mass loss of $C$. pentandra, for the two decay fungi, suggests that Trametes versicolor had a greater preference for this wood than the Gloeophyllum trabeum fungus. Regarding the Microphilis melinonian, the Gloeophyllum trabeum fungus showed a greater preference for this wood species, with a smaller difference in mass loss caused by both fungi.

Fackler \& Schwanninger (2012) corroborate this result, stating that the decaying classes of decay fungi have different metabolizing characteristics of the wood chemical components.

The comparison between mass loss and the classes of basic specific gravity from the studied species demonstrated how this physical property is an important variable with great influence on the wood resistance, also taking into account the influence of the wood chemical components and its characteristics. Moreover, Silveira et al. (2013) consider this property as a quality parameter in the furniture industry, resulting from the combination of several factors such as fiber dimensions, cell wall, vessels and proportions, in addition to anatomical arrangements, among others.

\section{Middle infrared spectroscopy}

The absorbance spectra of the four wood species before the attack of the decay fungi (reference) and after it are illustrated in Figure 2.

Results from the bands variations of the selected chemical components, in relation to the standardized bands of the reference samples, of the four wood species subjected to the two decay fungi, are following in Table 3.
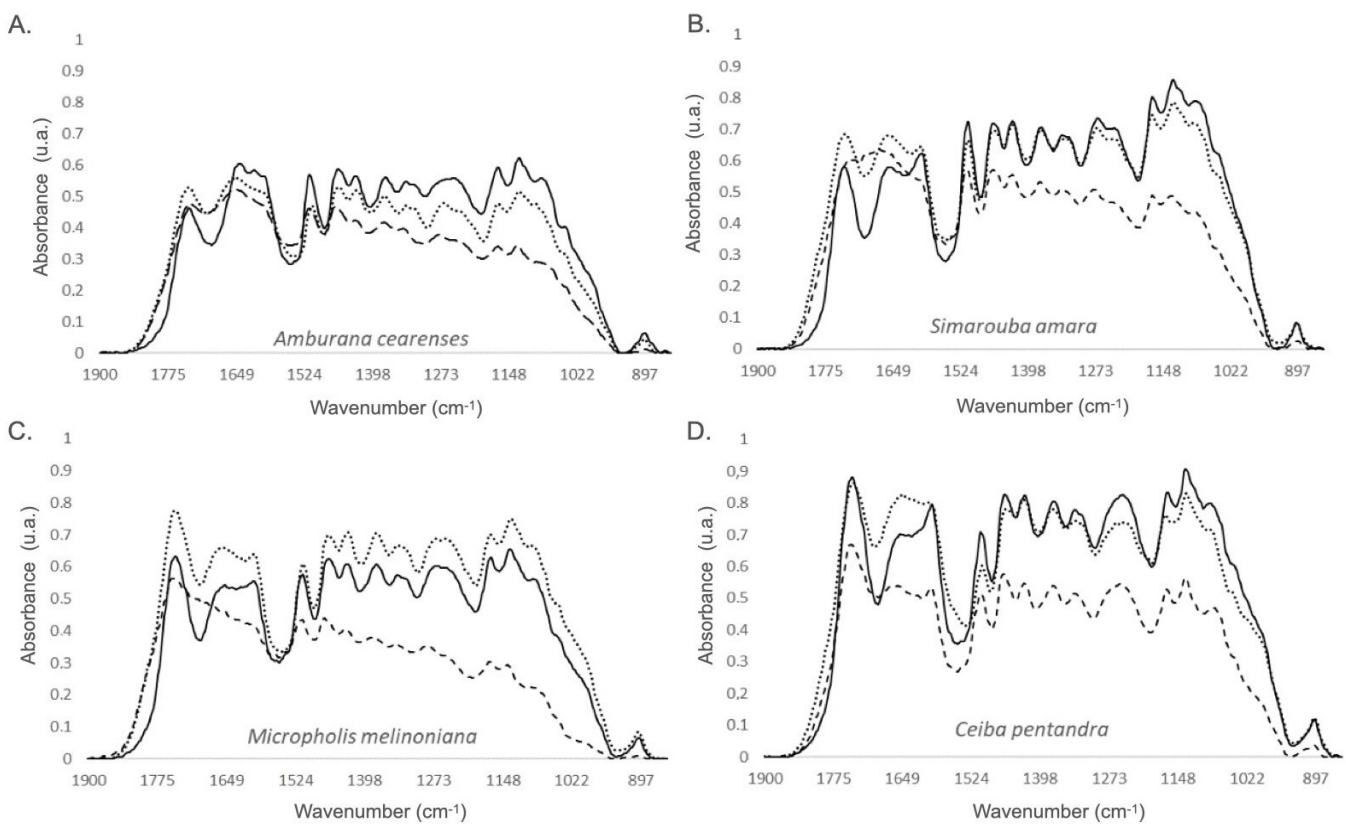

Figure 2. Absorbance spectra of the species Simarouba amara (A.), Ceiba pentandra (B.), Micropholis melinonian (C.) and Amburana cearenses (D.). The solid line represents the reference samples, the dotted one stands for the samples after the attack of the Trametes versicolor fungus and the dashed one is for the aftermath of the Gloeophyllum trabeum fungus attack in the wood species.

Table 3. Variations of bands intensity of the chemical components from the four wood species, before (reference) and after the attack of the fungi Gloeophyllum trabeum and Trametes versicolor.

\begin{tabular}{|c|c|c|c|c|c|c|}
\hline \multirow[b]{2}{*}{ Species } & \multirow[b]{2}{*}{ Treatments } & \multicolumn{5}{|c|}{ Bands $\left(\mathrm{cm}^{-1}\right)$} \\
\hline & & $\begin{array}{l}1510 \\
\text { (Lig.) } \\
\end{array}$ & $\begin{array}{l}1375 \\
\text { (Hol.) } \\
\end{array}$ & $\begin{array}{l}1160 \\
\text { (Hol.) } \\
\end{array}$ & $\begin{array}{c}1135 \\
\text { (Hem.) }\end{array}$ & $\begin{array}{c}899 \\
\text { (Cel.) } \\
\end{array}$ \\
\hline \multirow{2}{*}{$\begin{array}{l}\text { Simarouba } \\
\text { amara }\end{array}$} & Reference & 1.00 & 1.00 & 1.00 & 1.00 & 1.00 \\
\hline & T. versicolor & 0.76 & 0.81 & 0.74 & 0.76 & 0.85 \\
\hline $\begin{array}{c}\text { Ceiba } \\
\text { pentandra }\end{array}$ & Reference & 1.00 & 1.00 & 1.00 & 1.00 & 1.00 \\
\hline \multirow{3}{*}{$\begin{array}{l}\text { Micropholis } \\
\text { melinoniana }\end{array}$} & Reference & 1.00 & 1.00 & 1.00 & 1.00 & 1.00 \\
\hline & G. trabeum & 0.43 & 0.32 & 0.27 & 0.44 & 0.17 \\
\hline & T. versicolor & 1.00 & 1.04 & 0.82 & 1.03 & 1.13 \\
\hline \multirow{3}{*}{$\begin{array}{l}\text { Amburana } \\
\text { cearenses }\end{array}$} & Reference & 1.00 & 1.00 & 1.00 & 1.00 & 1.00 \\
\hline & G. trabeum & 0.44 & 0.41 & 0.34 & 0.44 & 0.20 \\
\hline & T. versicolor & 0.56 & 0.78 & 0.70 & 0.65 & 0.67 \\
\hline
\end{tabular}

Lig: lignin, Hem: hemicellulose, Hol: holocellulose, Cel: cellulose. 
The results displayed in Table 3 reveals a preference of the fungus Gloeophyllum trabeum in metabolizing holocellulose, more intense in the cellulose represented by the $899 \mathrm{~cm}^{-1}$ band. Li et al. (2011) found a similar result, reporting that the brown rot fungi have a tendency for the alteration of the holocellulose in relation to the other wood chemical components.

The reduction in the remaining chemical components is due to brown rot fungi presenting a non-homogeneous deterioration, attacking the structural elements of the cell wall, which are arranged in a matrix consisting of polioses and lignins, in order to access its preferred components (Stangerlin et al., 2013).

The chemical components of the wood subjected to Trametes versicolor are deteriorated without distinction, which is thus reflected in the reduction of lignin and holocellulose bands. However, for Ceiba pentandra and Amburana cearenses, it was possible to notice a preference for the lignin deterioration, demonstrated in the more intense reduction of the $1510 \mathrm{~cm}^{-1}$ band. Depending on the ability to deteriorate lignin selectively or simultaneously with holocellulose, the white rot fungi may behave differently during the deterioration stages or depending on the affected wood (Rudakiya \& Gupte, 2019; Gilani et al., 2017; Valette et al., 2017).

\section{Gravimetric chemical analysis}

For the variations of chemical constituents in the gravimetric analysis (Table 4), possible increases in a certain content, after the decay fungi action, do not indicate a quantitative increase in this component. It means that, in relation to the total percentage of the analyzed chemical constituents, a given wood component had its content increased when compared to the remaining ones, resulting from the enzymatic action of the fungi.

Overall, after the attack of the G. trabeum fungus, a reduction in the holocellulose content occurred, except in the Amburana cearenses. Pandey \& Pitman (2003) and Li et al. (2011) found a similar result when demonstrating this fungus preference for cellulose and hemicellulose of wood, a factor that may explain the increase in the contents of total lignin and extractives.

T. versicolor has the ability of metabolizing cellulose, hemicellulose and lignin (Valette et al., 2017). In the present study, for Simarouba amara, this fungus preferentially metabolized holocellulose, while for samples of Ceiba pentandra, Microphilis melinonian and Amburana cearenses there was a reduction in lignin content, with a consequent increase in the contents of holocellulose and extractives. Pandey \& Nagveni (2007) observed a preference for lignin when working with white rot fungus and other wood species.

In general, the content of extractives present in the four wood species had an increase (except Micropholis melinonian and Amburana cearenses, after the $T$. versicolor action), in view of an increase in the extractives proportion that was observed after the fungi action, in relation to the residual mass of the wood samples. This result may suggest that the fungi did not show any preference for the extractives components, but their presence did not prevent the wood deterioration. Mounguengui et al. (2016) and Carneiro et al. (2009) found that regardless of the extractives photochemical nature, their proportion in the wood directly influenced the colonization by fungi, which together with the basic specific gravity contributed to the lower mass losses for Amburana cearenses.

The ash content increased, regardless of the decay class, with the exception of Amburana cearenses, indicating that the decay fungi did not show any preference for this wood chemical component.

The different behavior of Amburana cearenses can be explained by its resistance to the action of xylophagous fungi, which, regardless of their preferences, needed to modify in some way the extracts and the ashes, aiming to enable the access to the constituents of their metabolic preference (Stangerlin et al., 2013).

In relation to the spectroscopy and gravimetric analyzes, a general preference of the $G$. trabeum fungus for the

Table 4. Mean values of the chemical components from the four wood species before (reference) and after the attack of the Trametes versicolor and Gloeophyllum trabeum fungi.

\begin{tabular}{|c|c|c|c|c|c|c|c|}
\hline \multirow{2}{*}{ Species } & \multirow{2}{*}{ Treatments } & \multicolumn{6}{|c|}{ Chemical components (\%) } \\
\hline & & Ext & Ll $\mathrm{e}_{\mathrm{e} . \mathrm{f}}$ & LS $_{\text {e.f. }}$ & $\mathbf{L T}_{\text {e.f. }}$ & $\mathrm{Cz}_{\text {e.f. }}$ & $\mathrm{Hc}_{\text {e.f. }}$ \\
\hline \multirow{2}{*}{$\begin{array}{c}\text { Simarouba } \\
\text { amara }\end{array}$} & Reference & $2.07 \mathrm{~b}$ & $30.01 \mathrm{c}$ & $1.46 \mathrm{C}$ & $31.46 \mathrm{c}$ & $0.30 \mathrm{a}$ & $68.24 a$ \\
\hline & G. trabeum & $10.59 \mathrm{a}$ & $\uparrow 41.88 \mathrm{a}$ & $\uparrow 1.96 \mathrm{~b}$ & $\uparrow 43.84 a$ & $\uparrow 0.43 a$ & $+55.73 \mathrm{e}$ \\
\hline \multirow[b]{2}{*}{ Ceiba pentandra } & Reference & $1.71 \mathrm{C}$ & $17.91 \mathrm{~b}$ & $4.57 \mathrm{a}$ & $22.48 b$ & $0.66 \mathrm{c}$ & $76.87 \mathrm{~b}$ \\
\hline & G. trabeum & $\uparrow 9.11 \mathrm{a}$ & $\uparrow 26.90 \mathrm{a}$ & $\uparrow 4.95 \mathrm{a}$ & $\uparrow 31.85 \mathrm{a}$ & 个1.16 a & $\downarrow 66.99 \mathrm{c}$ \\
\hline \multirow{2}{*}{$\begin{array}{l}\text { Micropholis } \\
\text { melinoniana }\end{array}$} & G. trabeum & $\uparrow 6.33$ a & 个34.13a & $\uparrow 2.44 \mathrm{a}$ & $\uparrow 36.57 \mathrm{a}$ & $\uparrow 1.00 \mathrm{a}$ & $\downarrow 62.44 \mathrm{c}$ \\
\hline & T. versicolor & $\downarrow 2.33 \mathrm{~b}$ & $\downarrow 25.96 \mathrm{c}$ & $\uparrow 1.85 \mathrm{~b}$ & $\downarrow 27.81 \mathrm{c}$ & $\uparrow 0.71 \mathrm{~b}$ & $\uparrow 71.48 \mathrm{a}$ \\
\hline \multirow{3}{*}{$\begin{array}{c}\text { Amburana } \\
\text { cearenses }\end{array}$} & Reference & $12.25 \mathrm{~b}$ & 30.13 a & $1.48 \mathrm{c}$ & $31.61 \mathrm{a}$ & $1.53 \mathrm{a}$ & $66.87 b$ \\
\hline & G. trabeum & 个13.54 a & $\downarrow 26.49 b$ & $\uparrow 1.88 \mathrm{~b}$ & $\downarrow 28.36 \mathrm{~b}$ & $\downarrow 1.50 \mathrm{~b}$ & $\uparrow 70.14 \mathrm{a}$ \\
\hline & T. versicolor & $\downarrow 8.25 \mathrm{~b}$ & $\downarrow 29.23 \mathrm{a}$ & $\uparrow 2.09 \mathrm{a}$ & $\downarrow 31.32 \mathrm{a}$ & $\downarrow 1.20 \mathrm{c}$ & $\uparrow 67.48 \mathrm{~b}$ \\
\hline
\end{tabular}

Ext: extractives content; $\mathrm{LI}_{\text {e.f. }}$ : extractive-free insoluble acid lignin content; $\mathrm{LS}_{\text {eff }}$ : extractive-free soluble acid lignin content; $\mathrm{LT}_{\text {ef. }}$ : total extractive-free acid lignin content; $\mathrm{CZ}_{\mathrm{eff}}$ : extractivefree ash content at $525 \stackrel{\circ}{\circ} \mathrm{C} ; \mathrm{Hc}_{\text {ef }}$ : extractive-free holocellulose content. $\downarrow \uparrow$ : indicates the direction of the contents variation in relation to the reference of each species. Means followed by the same letter in the column do not differ from each other, for each wood, at the $5 \%$ significance level. 
carbohydrates from the four wood species was observed, result also verified in the reduction of the holocellulose content and the bands 1375, 1160, 1135 and $899 \mathrm{~cm}^{-1}$.

The $T$. versicolor fungus ability in metabolizing both holocellulose and lignin was also observed, resulting in the reduction of all selected bands and more intense in the 1510 $\mathrm{cm}^{-1}$ band.

The different behavior pattern of Amburana cearenses can be explained by the spectroscopy analysis being restricted to the specimen surface, where the fungi hyphae were more intense due to the greater resistance of this species. In the gravimetric analysis though, the evaluation was performed on the specimen as a whole, transformed into particles.

\section{Principal Component Analysis (PCA)}

Multivariate statistical methods were employed in order to allow the analysis of larger spectral portions, instead of the isolated bands, and the chemical contents of the wood components, together with the mass losses.

Resulting from the PCA, two graphs are then generated; the score one, defining the treatments position in relation to the main components, and the loadings one, which expresses the influence of each original variable on the main components.

Figures $3 \mathrm{~A}$ and $\mathrm{BB}$ display the score and loading graphs of the main components performed with the intensity values of the medium infrared spectra. The first two components (PC1 and PC2) were responsible for explaining $89.53 \%$ of the data variation.

Statistical analysis of main components allowed the evaluation of larger spectral portions in addition to the selected bands. In Figure $3 \mathrm{~A}$ there is a tendency of grouping according to the treatments (before and after the attack of the decay fungi), evidenced by the dashed lines. In Figure 3B, it is possible to observe which bands had the greatest influence on the treatment arrangement.

In the PCA, the wavelengths responsible for the discrimination and consequently the distribution of the treatments are those that have the highest positive and negative weights. In the first main component (PC1), the bands with the highest positive weights were $1695 \mathrm{~cm}^{-1}$ and $1771 \mathrm{~cm}^{-1}(0.095$ and 0.073 , respectively), and with the largest negative weight at $1119 \mathrm{~cm}^{-1}(-0.078)$. In the second component (PC2) though, the band that exerted the greatest positive influence was the $1746 \mathrm{~cm}^{-1}$ (0.141), while the negative was the $1520 \mathrm{~cm}^{-1}(-0.144)$.

It is noteworthy that the bands $1695 \mathrm{~cm}^{-1}, 1746 \mathrm{~cm}^{-1}$ and $1771 \mathrm{~cm}^{-1}$ are within the range of the wave number referring to the stretching vibration of the $\mathrm{C}=\mathrm{O}$ bond, which can represent the carbonyl of the hemicelluloses, as well as the connections of aromatic lignin rings (González-Peña \& Hale, 2011; Varga et al., 2017). On the other hand, the $1520 \mathrm{~cm}^{-1}$ band is very close to the region representing the aromatic lignin skeleton (González-Peña \& Hale, 2011; Duca et al., 2016; Varga et al., 2017; Rudakiya \& Gupte, 2019). The $1119 \mathrm{~cm}^{-1}$ band is close to the region representing the vibration of $\mathrm{C}-\mathrm{H}$ in lignin and the $\mathrm{C}-\mathrm{O}$ stretching in cellulose $\left(1122 \mathrm{~cm}^{-1}\right)$, thus representing, in a way, the lignin/cellulose ratio (Traoré et al., 2016).

The component PC 1 was the one with the greatest weight in the treatments segregation in relation to fungi, occurring especially by the differentiation of wood metabolization indicated in the spectra by them. The spectra of wood damaged by $G$. trabeum are those that had the greatest change in relation to the reference (Figure 2), resulting from their holocellulose preference. In the region of the 1771 and $1695 \mathrm{~cm}^{-1}$ bands, there was an overlap of the adjacent bands, represented by the reduction of the valley regions, while the $1119 \mathrm{~cm}^{-1}$ band had a severe reduction in the absorbance intensity.

Regarding the PCA for gravimetric chemical analyzes, Figures $4 \mathrm{~A}$ and $4 \mathrm{~B}$ illustrates the score graphs and weights of the main components of the contents from the chemical constituents and the mass loss. The first two components (PC1 and PC2) explained $72.72 \%$ of the variation between treatments.
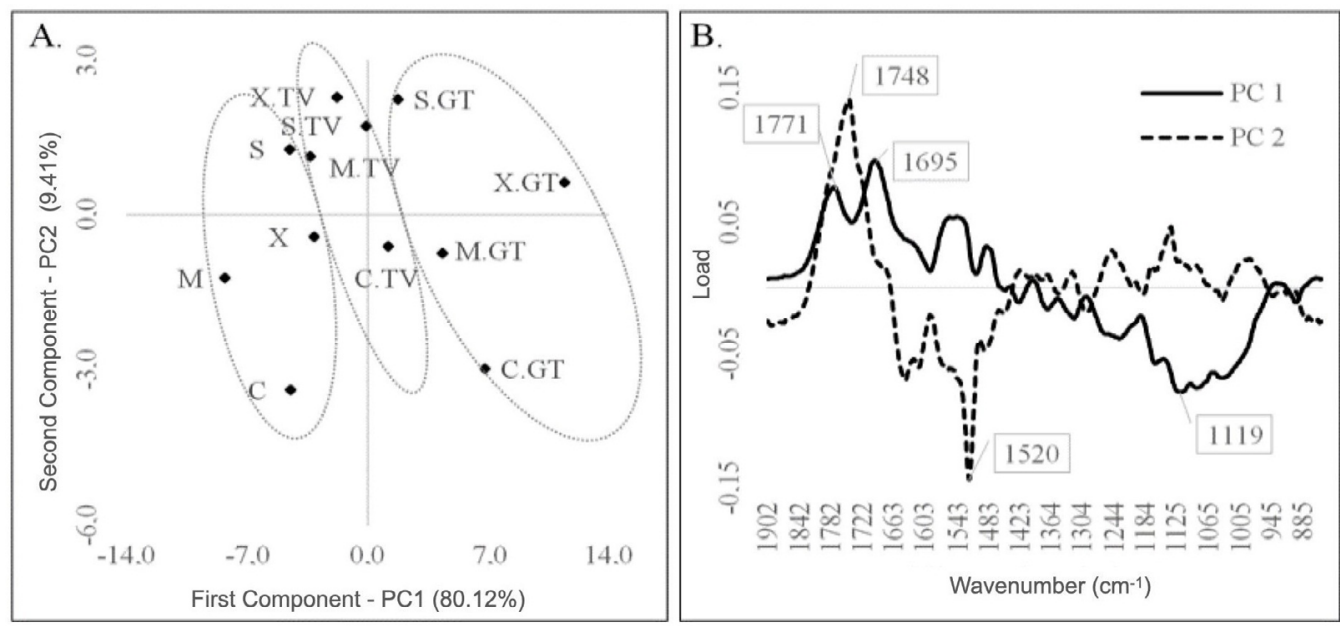

Figure 3. A. Score and B. Loading graphs of the principal components 1 and 2, explaining variations in treatments: before and after exposure to decay fungi. M: Simarouba amara, S: Ceiba pentandra, X: Micropholis melinoniana, C: Amburana cearenses, TV: Trametes versicolor, GT: Gloeophyllum trabeum. 

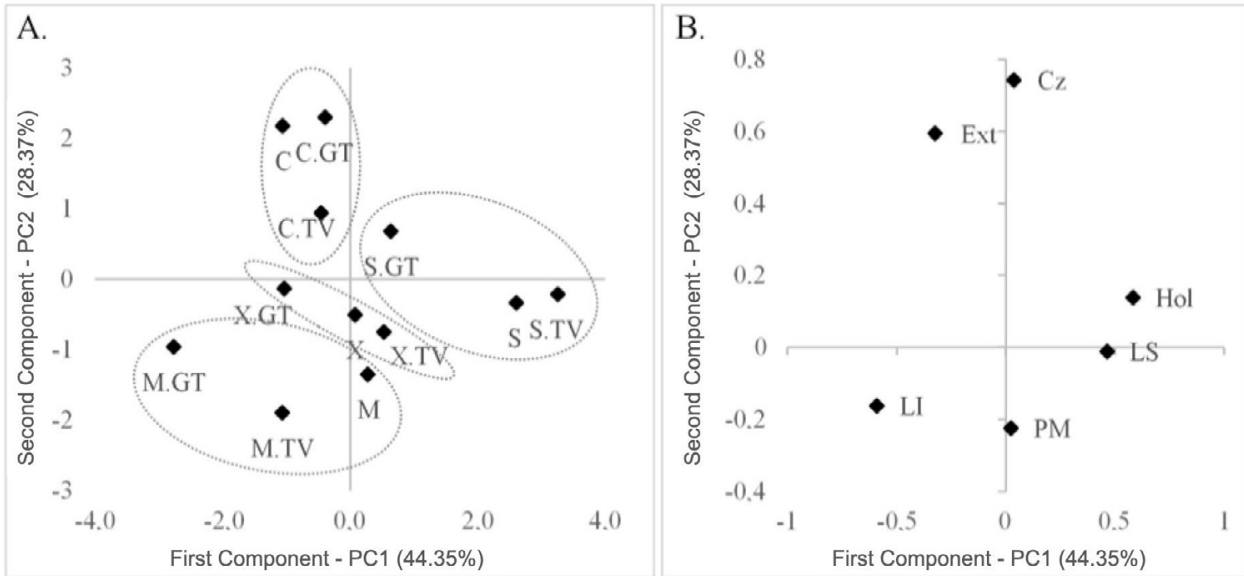

Figure 4. A. Score and B. Loading graphs of the principal components 1 and 2, explaining the variations of the treatments: before and after exposure to decay fungi. M: Simarouba amara, S: Ceiba pentandra, X: Micropholis melinoniana, C: Amburana cearenses, TV: Trametes versicolor, GT: Gloeophyllum trabeum, Ext: extractives content, LS: soluble acid lignin content, LI: insoluble acid lignin content, $\mathrm{Cz}$ : ashes content at 525 으, Hol: holocellulose content, PM: mass loss.

In Figure 4A, a tendency for grouping treatments according to the species of wood is observed, evidenced by the dashed circumferences. In Figure 4B, the variables that influenced the treatment arrangement are found.

In the first component (PC1), the variables with the highest weights were the following: holocellulose content (0.58), soluble acid lignin content (0.46) and insoluble lignin (-0.59). In the second component (PC2), the most significant variables were the contents of ash (0.74) and extractives, with negative relation (-0.59).

As for PC1, the lignin and holocellulose contents were responsible for the horizontal distribution, ensuring that within the Simarouba amara and Micropholis melinonian group the pattern was followed, from left to right, with the subjected to $G$. trabeum first, due the preference for holocellulose, and afterwards the $T$. versicolor, due to the preference for lignin, reflected in the reduction of the insoluble acid lignin content.

In relation to $\mathrm{PC2}$, the contents of extractives, ash and mass loss were responsible for the arrangement of treatments in the vertical, causing Amburana cearenses, which had the highest contents of them and the lowest mass loss, to rank higher. Due to the mass loss, the pattern is perceived within each group, where the material deteriorated by the $T$. versicolor fungus was lower in relation to $G$. trabeum in this case, since this fungus caused greater mass loss.

In the PCA (Figure 3) the distinction between the groups, with the medium infrared data, was possible due to the variations in the bands intensities, reflecting the changes in the chemical bonds caused by the fungi. Thereby, it was possible to distinguish treatments by the decay fungus. However, the result from the second PCA analysis (Figure 4) was due to the contents from the main constituents of the wood being an intrinsic characteristic of each wood, and that they, after the fungi action, continued to reflect this characteristic.

Moreover, the deterioration capacity of the wood components differed according to the species and its chemical structure, as well as the class of the decay fungus (Traoré et al., 2016; Sedighi-Gilani et al., 2017), a behavior broken down in the analysis of main components according to the chemical used analysis. Therefore, the medium infrared spectroscopy, a non-destructive analysis, showed potential for the discrimination of wood decay fungi.

\section{Conclusions}

After the action of the fungi $T$. versicolor and G. trabeum, the wood of Simarouba amara and Ceiba pentandra were considered as little resistant or not resistant at all; the Micropholis melinonian was moderately resistant; and Amburana cearenses was resistant to both decay fungi.

Chemical analyzes allowed to distinguish the action mechanisms of both decay fungi in relation to the wood components. The $G$. trabeum fungus displayed the reduction in the holocellulose composition as its main characteristic, while the $T$. versicolor had a preference in deteriorating lignin for most species. In Simarouba amara wood, an indistinct deterioration of the chemical components was observed.

The principal component analysis, using the intensities of the medium infrared spectrum, allowed the distinction of groups according to the decay fungi. However, with the mass loss data and the contents of the wood main chemical components, it was possible to distinguish a specific group for each wood.

Spectroscopy in the medium infrared together with the multivariate analysis of the data, proved to be a great tool in the identification of wood decay fungi, helping to choose the most suitable chemical treatments for different interactions between fungi and wood. Increased research with this objective may favor the construction of a more robust and reliable database for fungi identification.

\section{Literature Cited}

American Society for Testing Materials - ASTM. ASTM D2017: Standard test method of accelerated laboratory test of natural decay resistance of woods. West Conshohocken: ASTM, 2005. 
American Society for Testing Materials - ASTM. ASTM D2395: Standard test methods for density and specify gravity (relative density) of wood and wood-based materials. West Conshohocken: ASTM, 2014.

Carneiro, J. S.; Emmert, L.; Sternadt, G. H.; Mendes, J.C.; Almeida, G. F. Decay susceptibility of Amazon wood species from Brazil against white rot and brown rot decay fungi. Holzforschung, v. 63, n. 6, pp. 767-772, 2009. https://doi.org/10.1515/HF.2009.119.

Costa, M. de A; da Costa, A. F.; Pastore, T. C. M.; Braga, J. W. B. Caracterização do ataque de fungos apodrecedores de madeiras através da colorimetria e da espectroscopia de infravermelho. Ciência Florestal, v. 21, n. 3, p. 565-575, 2011. https://doi. org/10.5902/19805098.

Duca, D.; Pizzi, A.; Rossini, G.; Mengarelli, C.; Pedretti, E.F.; Mancini, M. Prediction of hardwood and softwood contents in blends of wood powders using mid-infrared spectroscopy. Energy and Fuels, v. 30, n. 4, p. 3038-3044, 2016. https://doi.org/10.1021/ acs.energyfuels.5b02994.

Fackler, K.; Schwanninger, M. How spectroscopy and micro spectroscopy of degraded wood contribute to understand fungal wood decay. Applied Microbiology and Biotechnology, v. 96, n. 3, p. 587-599, 2012. https://doi.org/10.1007/s00253-012-4369-5.

Fackler, K.; Stevanic, J.S.; Ters, T.; Hinterstoisser, B.; Schwanninger, M.; Salmén, L. Localisation and characterization of incipient brownrot decay within spruce wood cell walls using FT-IR imaging microscopy. Enzyme and Microbial Technology, v. 47, n. 6, p. 257267, 2010. https://doi.org/10.1016/j.enzmictec.2010.07.009.

González-Peña, M.M.; Hale, M.D.C. Rapid assessment of physical properties and chemical composition of thermally modified wood by mid-infrared spectroscopy. Wood Science and Technology, v. 45, n. 1, p. 83-102, 2011. https://doi.org/10.1007/s00226-010-0307-9.

Gupta, B.S.; Jelle, B.P.; Gao, T. Application of ATR-FTIR spectroscopy to compare the cell materials of wood decay fungi with wood mould fungi. International Journal of Spectroscopy, v. 2015, article 521938, 2015. https://doi.org/10.1155/2015/521938.

Hammer, O.; Harper, D.A.T.; Ryan, P.D. PAST: Paleontological Statistics software package for education and data analysis. Palaeontologia Electronica, v. 4, n.1, article 4, 2001. https://palaeo-electronica. org/2001_1/past/past.pdf. 22 Jun. 2019.

Labbé, N.; Harper, D.; Rials, T. Chemical structure of wood charcoal by infrared spectroscopy and multivariate analysis. Journal of Agricultural and Food Chemistry, v. 54, n. 10, p. 3492-3497, 2006. https://doi.org/10.1021/jf053062n.

Lazzari, E.; Schena, T.; Marcelo, M.C.A.; Primaz, C.T.; Silva, A.N.; Ferrão, M.F.; Bjerk, T.; Caramão, E.B. Classification of biomass through their pyrolytic bio-oil composition using FTIR and PCA analysis. Industrial Crops and Products, v. 111, p. 856-864, 2018. https://doi.org/10.1016/j.indcrop.2017.11.005.

Li, G.Y.; Huang, L.H.; Hse, C.Y.; Qin, T.F. Chemical compositions, infrared spectroscopy, and X-ray diffractometry study on brownrotted woods. Carbohydrate Polymers, v. 85, n.3, p. 560-564, 2011. https://doi.org/10.1016/j.carbpol.2011.03.014.

Mahajan, S.; Jeremic, D.; Goacher, R.E.; Master, E.R. Mode of coniferous wood decay by the white rot fungus Phanerochaete carnosa as elucidated by FTIR and ToF-SIMS. Applied Microbiology and Biotechnology, v. 94, n. 5, p. 1303-1311, 2012. https://doi. org/10.1007/s00253-011-3830-1.
Melo, J.E.; Coradin, V.T.R.; Mendes, J.C. Classes de densidade para madeiras da Amazônia brasileira. In: Congresso Florestal Brasileiro, 6., 1990, Campos do Jordão. Anais ... São Paulo: SBS/ SBSF, 1990. v.3, p.695-699.

Paes, J. B.; Morais, V. de M.; Lima, C. R. de. Resistência natural de nove madeiras do semi-árido brasileiro a fungos xilófagos em condições de laboratório. Revista Árvore, v. 28, n.3, p. 275-282, 2004. https://doi.org/10.1590/S0100-67622004000200014.

Pandey, K. K.; Pitman, A. J. FTIR studies of the changes in wood chemistry following decay by brown-rot and white-rot fungi. International Biodeterioration and Biodegradation, v. 52, n. 3, p. 151-160, 2003. https://doi.org/10.1016/S0964-8305(03)000520.

Pandey, K.K.; Nagveni, H.C. Rapid characterization of brown and white rot degraded chir pine and rubberwood by FTIR spectroscopy. Holz als Roh und Werkstoff, v. 65, n. 6, p. 477-481, 2007. https:// doi.org/10.1007/s00107-007-0181-9.

Perrin, D.; Gelhaye, E.; Gérardin, P. Total phenolic and lignin contents, phytochemical screening, antioxidant and fungal inhibition properties of the heartwood extractives of ten Congo Basin tree species. Annals of Forest Science, v. 73, n. 2, p. 287-296, 2016. https://doi.org/10.1007/s13595-015-0514-5.

Rudakiya, D.M.; Gupte, A. Assessment of white rot fungus mediated hardwood degradation by FTIR spectroscopy and multivariate analysis. Journal of Microbiological Methods, v. 157, p. 123-130, 2019. https://doi.org/10.1016/j.mimet.2019.01.007.

Sedighi-Gilani, M.; Heeb, M.; Huch, A.; Fink, S.; Scwarze, F.W.M.R. Fracture in Norway spruce wood treated with Physisporinus vitreus. Wood Science and Technology, v.51, n.1, p.195-206, 2017. https://doi.org/10.1007/s00226-016-0873-6.

Silveira, L.H.C.; Rezende, A.V.; Vale, A.T. Teor de umidade e densidade básica da madeira de nove espécies comerciais amazônicas. Acta Amazônica, v. 43, n. 2, p. 179-184, 2013. https://doi.org/10.1590/ S0044-59672013000200007.

Stangerlin, D. M.; Melo, R. R. de; Garlet, A.; Gatto, D. A. Durabilidade natural de painéis aglomerados confeccionados com Eucalyptus grandis e Bambusa vulgaris em ensaio de apodrecimento acelerado. Ciência Rural, v. 41, n. 8, p. 1369-1374, 2011. https:// doi.org/10.1590/S0103-84782011000800012.

Stangerlin, D.M.; Costa, A.F. da; Garlet, A.; Pastore, T.C.M. Resistência natural da madeira de três espécies amazônicas submetidas ao ataque de fungos apodrecedores. Ciência da Madeira, v.4, n.1, p. 15-32, 2013. https://doi.org/10.12953/2177-6830.v04n01a02. Technical Association of the Pulp and Paper Industry - TAPPI. T 204 om-88: Solvent extractives of wood and pulp. Atlanta: Technical Association of the Pulp and Paper Industry - TAPPI. 1988.

Technical Association of the Pulp and Paper Industry - TAPPI. T 211 om-93: Ash in wood, pulp, paper and paperboard: combustion at 525ㄷ. Atlanta: Technical Association of the Pulp and Paper Industry - TAPPI. 1993.

Templeton, D., Ehrman, T. LAP - 003: Determination of Acidinsoluble Lignin in Biomass. Golden: National Renewable Energy Laboratory, 1995.

Templeton, D., Ehrman, T. LAP - 004: Determination of Acidsoluble Lignin in Biomass. Golden: National Renewable Energy Laboratory, 1995. 
Traoré, M.; Kaal, J.; Martínez Cortizas, A. Application of FTIR spectroscopy to the characterization of archeological wood. Spectrochimica Acta - Part A: Molecular and Biomolecular Spectroscopy, v. 153, p. 63-70, 2016. https://doi.org/10.1016/j. saa.2015.07.108.

Tsuchikawa, S.; Kobori, H. A review of recent application of near infrared spectroscopy to wood science and technology. Journal of Wood Science, v. 61, n. 3, p. 213-220, 2015. https://doi. org/10.1007/s10086-015-1467-x.
Valette, N.; Perrot, T.; Sormani, R.; Gelhaye, E.; Morel-Rouhier, M. Antifungal activities of wood extractives. Fungal Biology Reviews, v. 31, n. 3, p. 113-123, 2017. https://doi.org/10.1016/j. fbr.2017.01.002.

Varga, D.; Tolvaj, L.; Tsuchikawa, S.; Bejo, L.; Preklet, E. Temperature dependence of wood photodegradation monitored by infrared spectroscopy. Journal of Photochemistry and Photobiology A: Chemistry, v. 348, p. 219-225, 2017. https://doi.org/10.1016/j. jphotochem.2017.08.040. 